\title{
Assessing Human Reproductive Cloning and Creationism from the Perspectives of Raelianism and African Belief
}

\author{
Peter Ottuh \\ Department of Religious Studies and Philosophy, \\ Delta State University, Abraka, Nigeria. \\ Email: pottuh@deslsu.edu.ng
}

\begin{abstract}
This paper appraised the issues involved in human reproductive cloning and creationism from the standpoints of Raelian religion and African traditional belief. The methods adopted are descriptive and evaluative. The findings include the fact that human cloning is one of the religious tenets of Raelianism; and that African tradition and culture totally reject reproductive cloning on the ground of its unnaturalness. Finally, the paper from the African traditional paradigm concluded that human reproductive cloning is totally condemnable and should not be practiced on human beings on the ground of unnaturalness, distortion, negation, imperfection, and aberration.
\end{abstract}

Keywords: Reproductive Cloning; Creationism; Raelian, African; Tradition.

\section{INTRODUCTION}

Human reproductive cloning in its methods is the most despotic and slavish form of genetic manipulation. This is because, the technology amounts to unnatural constitutiveness of human rationality which is devoid of the principles of procreationism that defines all humans as biological entities. Taking into cognizance, some reasons for pursuing the human cloning enterprise are recognizable and acknowledgeable, while others are shocking. Those that are recognizable mostly, is the fact that reproductive cloning is another possible option for the (attempted) remedy of infertility which is parallel to earlier technologies that once shocked or disturbed the world, e.g. artificial insemination (AI) and in-vitro fertilization (IVF) (Ottuh, 2008, pp. 311). Reasons advanced for human cloning are anchored on human freedom (human rights) or freewill which is also discoverable in modernism, liberalism, moral choices, protecting and promoting scientific and technological researches, and so on.

The shocking reasons for cloning are not illegitimate just because they run against the grain of our prejudices. For it may be that our present-day moral presumptions are misguided, and that a rational case for humanitarian or evolutionary eugenics deserves a fair hearing, and that its various advocates deserve at least some room to offer and prove their case or pursue their ideals. And while such ideals offer direct challenges to our idea of civilization, the truth is that our values and purposes are not the only morally justifiable ones, and our civilization is not likely to be the last form of human civilization in human history (Edor \& Odok, 2010). As a 


\section{Jurnal Office: Jurnal Pemikiran Ilmiah dan Pendidikan Administrasi Perkantoran \\ Vol. 6, No. 1, January-June 2020, Page 81-96}

further contribution to the human cloning debate, this paper wishes to examine human reproductive cloning and the philosophico-theological concept of creationism and appraise same from the perspectives of the Raelian and African traditions.

The argument for cloning humans can be termed as genuinely shocking purpose because; human cloning technologies are not illegitimatizing just because they run against granulate of human prejudices. For it may be that human present-day righteous presumptions are misguided, and that a sensible conjuncture for evolutionary eugenics deserves a fair synthesis, and that its various advocates find merit at least in some scope to offer and prove their cases or promote their ideals. And while such ideals tender immediate defiance to our idea of refinement, the reality is that our values and instance are not the only virtuously authorizable one, and our enlightenment is not agreeable to be the last elegance of human culture in human tale. As a further contribution to the mortal cloning discussion, this paper examined human reproductive cloning and the philosophico-theological concept of creationism and appraised same from the perspectives of the Raelianism and African traditional beliefs.

\section{MEANING OF HUMAN REPRODUCTIVE CLONING}

Etymologically, the word, "clone" is derived from the Greek word, "Klon" meaning to "twig" or to "slip" in plants (Varga, 1980, pp. 119). In botanical science, the word, "clone" implies "cuttings" in plants. It is a botanical process of asexual reproduction (or Vegetative propagation) in plants (Stone \& Cozens, 1975, pp. 259-261 cf. Gogarty 2003, pp. 85). In this apprehension, a "clone" is produced from a single origin. In unregenerate world, clones are found in organisms capable of neuter reproduction that is, in certain plants and bacteria. "Cloning" therefore, is a scientific technique that embarrass creation of a hereditary fold of an already existing animal or plant (Varga, 1980, pp. 119). It can also imply the creation of a hereditary copy or transcript of a DNA (Deoxyribonucleic Acid) sequence, a cell, not just the entire organization. In its simplest definition, cloning is the production of multiple identical lineages. The result of cloning is a clone. The term here refers to the cloning of non-humans and humans. Typology of human cloning includes therapeutic and reproductive cloning.

Reproductive cloning is also denominated as Adult DNA cloning. This technique is intended to produce a double of an existing human being. It has been used to clone animals and other mammals in the past (Zhu \& Huangfu, 2013, pp. 92). In this technique, the DNA from an ovum is extracted and replaced with the DNA from a cell removed from an adult creature. Then, the "inseminated" ovum, now called a "pre-embryo," is instilled in a venter and bestows to evolve into a new animal (clone) (Chung et al., 2014. pp. 142). As at 2002, this technique has not been used on human beings. This is because, it is specifically forbidden by law in many nations of the world. Although, there are rumors that some scientists have successfully initiated a pregnancy through reproductive cloning (Kennedy 201). This type of cloning has the potentiality of producing or creating a twin from an existing human person or animal.

Based on previous zoological studies, reproductive cloning also has the potentiality of producing severe genetic defects (Zhu \& Huangfu, 2013, pp.110). For this reason only, most medical ethicists consider it to be a proudly non-moral procedure when carried out on human 
beings. In human cloning, two basic methods are identified. These are artificial twining and nuclear transfer methods. Natural twining is already occurring in nature when for instance in humans, identical twins or triplets are born. This happens naturally when the fertilized egg (zygote), in its early development, divide into two or more separate parts, each then develops into a genetically identical individual. By imitation of this natural process, in the 1980s it is believed that this same process was artificially stimulated in cattle, and cows (Oregon Health \& Science University, 2013, pp. 113). The first proof in artfully stimulating twining in humans was done in 1993 by researchers in George Washington University in Washington, U.S.A (cf. De-Grey \& Rae 2007, pp. 351). The researchers were afore said to have circumspectly achieved their cloning experiments on genetically exceptional embryos that had no chance of survival. This procedure is used as a way of multiplying human embryos. It has also been used widely in beastly models.

The second method is called, "Nuclear Transfer" (NT) (or Somatic Nuclear Transfer or Nuclear Substitution). It involves passing the nucleus from diploid cell (i.e. include 30-40,000 genes and full adapt of paired chromosomes) to an unfertilized egg cell from which the maternal nucleus has been removed or enucleated. First, in nuclear transfer, clonists extract an unfertilized egg cell from a female, and enucleate (remove) the cell's nucleus from it (note that the cell nucleus contains the DNA). From the animal to be cloned, clonists obtain a suitable cell, such as a skin cell, the nucleus which contains its owner's genetic blueprint. Next, the cell is introduced into the enucleated egg and elapse and thrilling current through it. This fuses the cell with the egg cytoplasm. With its new nucleus, the egg now disunite and grows as if it were inseminated, and a clone of the creature from which the embody utricle was taken begins to grow into term. The embryo can them be inoculated in the womb of subrogate- mother, where, in a rare instance when all goes well, it will increase to term.

Alternatively, the rudimentary may be kept only until the inner cell mass can be used to obtain embryonic stem cells that can be kept in culture. Scientists trust that this basic protuberance should be applied to human beings with a survey to receiver embryonic shaft theca (Thomas, 2013, pp. 148). Nuclear transfer process was used in 1952 to study early development in frogs and in the 1980s the technique was used to clone cows and sheep using cells taken directly from early embryo. It was this process that Ian Wilmut and Keith Campbell applied in cloning Dolly, the first matured cloned beast (Peters, 2001, pp. 31). However, the success of this technique in animals raises fears and creates tension among scientists and the public for the purpose of using the procedure to clone humans. This fear has led to massive reactions around the globe. All the cloning methods described above have their potential risks and benefits. The reason for cloning humans can be classified into liberal and eugenic reasons.

The noble purposes of cloning are recognizable and defensible within the firm of "core values" of neoteric liberal democracy (President's Commission on Bioethics 429). The liberal purposes of cloning include the following:

a. it enables couples who cannot produce children to do so biologically with related identity;

b. it allows nontraditional associate and individuals especially of the same gender to have children who are biologically related to themselves;

c. it permits people to have children without the peril of known genetic diseases; 


\section{4| Jurnal Office: Jurnal Pemikiran Ilmiah dan Pendidikan Administrasi Perkantoran \\ Vol. 6, No. 1, January-June 2020, Page 81-96}

d. it provides kindred the opportunity to "replace" offspring who have died prematurely, including loved once who all of a sudden lose their living;

e. it allows parents to produce offspring who would be ideal graft donors for a desperately existing ill children; and

f. it will develop reproductive freedom and and reproductive choice.

On the other hand, eugenic reasons for reproductive cloning include the followings:

a. It is aimed at allowing families and society to reproduce individuals of great genius, talent, beauty, etc. who are presumed to be based on their desirable or superior genetic makeup;

b. To prepare society, for the unpredictable nature of the future, for instance, extreme circumstances may require the recreation of certain desirable genomes; and

b. Human cloning is considered to be the next step in human evolution, the gateway to the genetic self-improvement of mankind, and the desirable continuation of modem civilization's mastery of nature for the relief of man's estate (PCB, 2009, pp. 982).

These eugenic reasons for human cloning run against the grain of human prejudices. All the above mentioned reasons have their moral, ethical and scientific or medical implications.

For a better understanding of human reproductive cloning in the context of this paper, let us distinguish between sexual (natural) reproduction and reproductive cloning. Sexual reproduction is a natural form of reproduction in mammals (humans and animals).

In this sense, all mammals reproduce their offspring through this process. For this to occur, the sexual union between a male and a female is required. In this way, the male sperm swims to the ovum of the female to fertilize the egg. The sperm DNA (or Nucleus) enters and makes its way through the cytoplasm until it reaches the nucleus of the ovum. The two fuse together and become one (i.e. a final fertilization of the female's egg has taken place). This leads to forming early embryo (embryos as the case may be), and then develops into blastocyst (a pre-implantation embryo of 50-250 cells depending on age which is made up of an outer layer of cells also called trophectoderm), a fluid-filled cavity (the blastocoels), and a cluster of cells on the interior (the inner cell mass) from which a baby results including embryonic stem cells (see figure 1).

In human cloning (asexual reproduction), the process is artificial unlike that of sexual reproduction. In cloning, the DNA containing the nucleus of any specialized cell (except eggs and sperm, containing half the DNA present in other cells) is transferred into an oocyte (Developing egg, usually big and non-movable cell) whose own nuclear genome (genetic material) has been removed (see figure 1). The egg can then be activated to develop and will share to conventionality blastocyst after excessively the early rudimentary omnibus (cloned early embryo), whose genetic material and genetically resolute traits are identical with those of the donor of the particularize cell, not those of the donor of the oocyte. The oocyte does not afford a very weak amount of genetic information in the mitochondria (the energy warehousing of the cell), but the genes in the center are of overrule importance, for the immense ancestry of the traits of the mammal (animal or human being).

If such a blastocyst is moved to the uterus of a surrogate mother, the transferred blastocyst could potentially form into a baby (or a live-born offspring) - a clone of the nuclear donor. The blastocyst can be used also to derive embryonic stem cells from inner cell mass which in turn, can be grown in culture in the laboratory to become several different cell types (Nuclear Transfer 119). 
Researchers foresee the potential use of human embryonic stem cells to replace or restore damaged or diseased tissues. From a technical point of view, therapeutic and reproductive cloning differs only in the way in which the resulting embryos are treated, namely, whether they are converted to a tissue culture or transplantation intact to the womb.

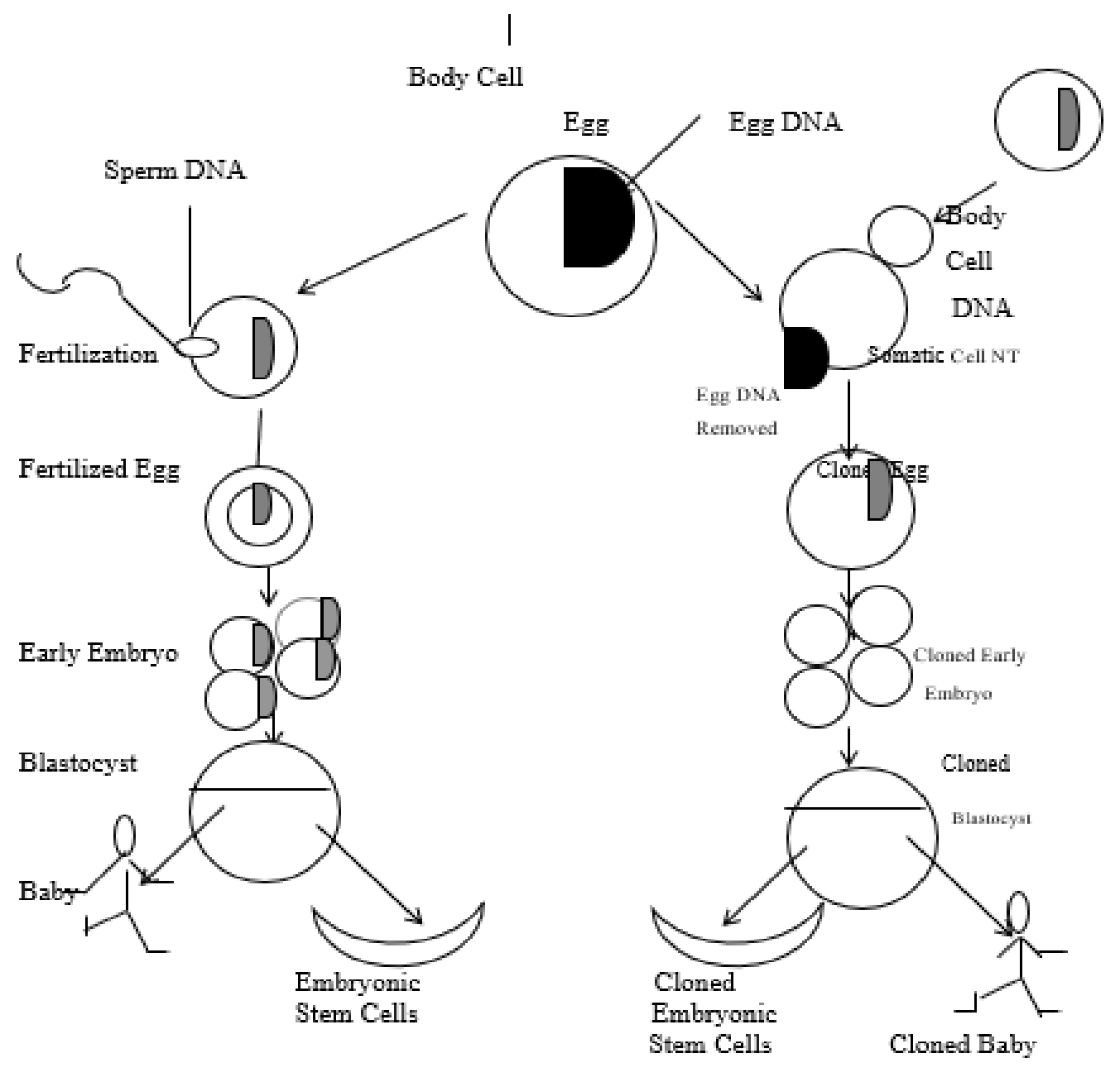

Source: (Ottuh, 2008, pp. 73)

Figure 1

Differences between Sexual Reproduction and Reproductive Cloning 


\section{6| Jurnal Office: Jurnal Pemikiran Ilmiah dan Pendidikan Administrasi Perkantoran}

Vol. 6, No. 1, January-June 2020, Page 81-96

\section{CREATIONISM AS A PHILOSOPHICO-THEOLOGICAL CONCEPT}

Creationism is a theological philosophical notion that is examined within the context of "Creation." By "creation" is meant to imply all that exists which is not God (Gen. 1\&2) (Mullins, 1972, pp. 251 cf. Peters, 2001, pp. 101). This includes nature and humans and all other forms of being other than God himself. The problem or concept of creation is one of the most difficult of all those with which the unaided reason of man tries to resolve. Modern physical science has given it acute form in its doctrine of the transformation of energy. In this sense, everything in nature is the transformed result of something prior in the causal series. The outcome is the endless regress of physical causes.

There seems to be a clear contrast, though not contradictory, between the method of physical science and that of religion and theology. In the former causation is expressed in terms of matter and energy, while, the latter is expressed in terms of spirit, freedom, and personality (Mullins, 1972, pp. 252). The difference between physical and free causation must therefore, be held clearly in the mind. In the above context, creationism as a Christian doctrine does not rely on the conclusions of physical science as these may relate to how the universe came into being. The Christian view that God is Creator, and that he brought the universe into existence is attested to by the Biblical accounts of Genesis (Gen. 1\&2): "God created the heavens and the earth. And the earth was void and formless: and darkness was upon the face of the waters." Furthermore: "And God said let there be light, and there was light, and God saw that it was good, and God divided the light from the darkness he called night. And there was evening and there was morning, on that day" (Mullins, 1972, pp. 254). According to the Bible, creation was completed on the sixth day (Genesis 2-3).

Amazing as it is, Anthony Flew describes the event or the story as "one of the most majestic vision in all literature" (cited in Mullins, 1972, pp. 251). If accepted as a myth, the Christian concept of creation can be seen as generally concerned with the ontological dependence of the world upon God. From this theological perspective, a characteristic feature of the creation doctrine is the assertion that it is "creatio de nihilo" meaning "creation out of nothing" (Flew 190). In the light of the foregoing, St. Augustine (in Hutching 7, 91) asserts that: ...neither in the heaven, nor in the earth, didst thou make heaven and earth, nor in the air, or waters, seeing these also belong to the heaven and the earth, nor in the whole world didst thons make the whole world because there was no place where to make it, before it was made, that it might be. Nor didst thons hold anything in thy hand, where to make heaven and earth.

In other words, Christians do not pursue the physical series of causes and effects, or the philosophical series of logical concepts, to prove that God created the universe. They rather pursue the personal and spiritual series given in the religious experience of human.

The physical and philosophical concepts of creation find strong confirmation in the scientific and rational processes (Edor 2016). That is, science confirms the view especially if we consider the development hypothesis. In this sense, its distinctive mark is progress from lower to higher forms. Science expressly precludes a self-originated beginning of all things; hence, a creator is needed. The logical and philosophical process also confirms the view expressed 
above. The reason calls for an uncaused cause of all things, which nature never yields. This means, that the will of man is in a relative sense, an originating cause, and from it we infer a spiritual first cause who brought the universe into being.

Mullins sums up the Christian concept of creation in the following manners:

a. that the universe while distinct from God, originated in his act and is dependent upon him,

b. that in creating the universe, God acted freely and not under necessity or compulsion,

c. that in creating the universe, God had in views moral and spiritual ends,

d. that the ends of God was the communication of his own life and blessedness to created beings (Gen.1:26),

e. that the Creator's supreme desire, is to make vast spaces for the habitation of sentient and intelligent beings, who will further replenish it through procreation (Gen. 1:28ff), and

f. that the end so defined, is an end begun, carried forward, and to be completed eschatologically (253).

One cannot understand creation with the exclusion of humans (i.e. the creation of human being in Gen. 1:26-27; 2:7ff). This is because, human is considered to be "the crown and good" of creation. Both science and religion agree remarkably in placing man at the end of the serves of graduations of nature. For instance, all the lower stages of creation preceded human in the account of genesis. According to science, humans sum all the past in themselves and then goes far beyond all lower stages. In human, creation attains a moral and spiritual level. This implies therefore, that, the lower stages of the higher one. In view of the above, we can infer that human:

a. consists of a physical and spiritual part-body and soul (Gen. 2:7);

b. has a striking peculiarity that makes human a connecting link between the physical and the spiritual universe;

c. that the spiritual nature of human consists of both soul and spirit;

d. was created by God, not through evolution; and

e. man is a free being (Mullins, 1972, pp. 255).

Opposing views against creationism can be found in several theories which have been proposed against the view that God called the universe into being by his creative act. These views can be summarized as follows:

a. the theory that matter alone is eternal and that all forms of mental and spiritual life are derived from matter. Although this theory ignores all the vital elements of being, mind, will, and conscience in a human being;

b. the theory of dualism. This holds that there are two eternal and self-existent principles: God and Matter. It holds that God did not create matter, but only used it for his ends. The limitation of this theory is that it is self-contradictory since two absolute or eternal existence cannot be held together satisfactorily in our thoughts;

c. that the universe is an emanation from God. In its more recent forms, it is either pantheistic as with Spinoza, idealistic as held by Hegel and some of his successors. This form negates the omnipotent nature of God; 


\section{8| Jurnal Office: Jurnal Pemikiran Ilmiah dan Pendidikan Administrasi Perkantoran}

Vol. 6, No. 1, January-June 2020, Page 81-96

e. that the universe is the eternal creation of God. The difficulty of explaining why God should have remained mute or idle through an eternity before beginning to create led to this view;

f. and lastly, the theory of evolution which proposed that organisms including human beings originated from pre-existing ones (Mullins, 1972, pp. 255).

\section{CREATIONISM AND HUMAN REPRODUCTIVE CLONING}

The call or command to participate in creation through procreation may underline the enthusiasm of scientists to engage in human cloning science. Infertile couples, for instance, may fill cheated or disobedient by not procreating, hence, they will resort to reproductive or therapeutic cloning to participate in procreation. By procreation, it seems to suggest that the world is incomplete or, that the creative act of God is progressive. Hence, cloning is one of such progressive processes to achieve a complete whole. Immortality is a further mark of the divine image in man. Human spirit survives after the death of the body in an endless existence. Hence, human replication could be one of those ways to achieve or promote human immortality. In order to produce children, procreation provides the really avenue in arguing for cloning including cloning to produce animals and plants.

Much of the time, most of us expect to take for granted this pivotal view of human life, through which all of us appear to be and through which we give birth to our descendants. The foresight of creating offspring by cloning conveys this subject acutely before us and compels us to investigate the nature and intent of human procreation. This worldview maintains that nature is so pervasively evil that it cannot be the basis for any developmental strategies or morality. To those who subscribe to this school of thought, man's nature is in crisis that demands concerted and well planned actions. For them, human society is constantly in strife and tension, because, the harmony between man and nature is disrupted; only a planned effort can change and restore this dignity and harmony. The theological dimension to this worldview, asserts that, the distortion and disharmony in nature started when Adam and Eve (first created human beings according to the Christian Bible) disobeyed God, their Creator (Gen. 3) (Hefley \& Lester 221).

Can human cloning technology be classified as one of those planned efforts to re-order the universe? As much as science and technology have played, and still playing important roles in promoting well-being of mankind, they have also affected human kind negatively by dehumanizing humankind in so many ways. Theologically (as in Christian theology) since distortion of nature started with the first human beings, its restoration to orderliness has been perfected through Jesus Christ, the Son of God (Lk. 1:31ff; John 3:16) (Hefley 226). Human cloning itself is destructive, and amounts to distortion, therefore, its constructive functions on a distorted nature or world, will amount to contradiction. The notion that humans are "cocreators" with God is anchored on the command of human domination over nature (cf. Gen. 1:28ff) (Seyyed, 2007, pp. 127). In cloning, this is interpreted in three significant ways:

a. One notion is an ethic of stewardship in which humans are entrusted with administrative abilities for creation, 
b. Human stewardship includes caring for and cultivating creation after the manner of a gardener; and

c. The stewardship ethic accepts the given -ness of nature as a good to be maintained and preserved. Particularly significant is the Jewish and Islamic discourses, which suggest a "partnership" of human beings with God in caring for and improving upon creation (Qur'an 6:165; Gen. 1:28) (Seyyed, , 2007, pp. 114). According to them, as participants in the act of creation with God, human beings can actively engage in advancing the well-being of humanity by intervening in the works of humankind, including the early level of embryonic evolution to improve human soundness (Campbell 2002, pp. 19). The above view, the native world is inseparably ductile, and can be arrange in several different forms in serving both divine and human goals. Thus, this notion (Re-constrnctionism or functionalism) holds the prospect for seeing cloning research, and perhaps some forms cloning humans as using human creative potential for good. Humans as "created co-creators", recognizes that humans are created and thus, depend on the Creator, yet they are finite and fallible in their existence.

Simultaneously therefore, human beings assume a role of co-creator to envision and implement knowledge for the betterment of humans and the universe as a whole. In this sense, humans are called to "play humans" through their freedom and responsibility in creating an essentially open human future. Therefore, human cloning can be one particular expression of responsible co-creatorship. However, humans have displayed an irremediable propensity to use their divinely authorized dominion for unauthorized dominion to violate their cerement of partnership with God-the Creator, and to create after their own image rather than the divine image. The potential that humans prefer evil rather than good, means caution is a moral necessity.

\section{RAELIANISM AND HUMAN REPRODUCTIVE CLONING}

Raelian is a religious cult founded by Rael, who is also the leader of the cult. The seat of the Raelian religion is the Montreal hinterland. Cloning is a tenet of the Raelian religion (or Cult) (NBAC 4531). Historically, this cult may sound inauspicious, but it is seriously committed to cloning technology. According to Michael Bishop, Raelianism dedicated its considerable resources to solving human cloning problem (cited in Javiti, et al., 2006, pp. 43). Rael, the leader of the cult, claims to have been abducted and molested by "voluptuous robots" visiting the earth in a UFO (unidentified flying object) in 1973 and thereafter received his cloning inspiration. The Raelians believe that humankind is placed on earth by some intelligent beings from another planet that produced the first "earthmen" by way of cloning technology (Javiti et al 44). Rael noted that: "Cloning is a religious process for the Raelians, and it will give us immortality which is the genetics of the Bible" (Javiti et al 2006). The Raelians have two major advantages over most of the other groups in the full business of cloning enterprise. Firstly, they have admittance to a rich supply of donated female eggs and secondly, they have at least fifty or enough of their female members who have volunteered to personate as surrogate mothers for the cloned embryos (cf. Araujo, 2007, pp. 111). The Raelian cult also has chief scientists, scientists and clinicians to promote their cloning enterprise. It was once reported that the scientific team of the Raelian cult claimed to have implanted the first cloned human embryo by the end of March, 2001 (cf. Araujo 2007, pp. 112). The Raelians also have made numerous unsubstantiated claims that they have produced children using nuclear transfer (cloning). 
90| Jurnal Office: Jurnal Pemikiran Ilmiah dan Pendidikan Administrasi Perkantoran

Vol. 6, No. 1, January-June 2020, Page 81-96

The conclusion to be drawn from the above discussion is that, the Raelian, as a religious group supports human reproductive cloning in its fullest. Some religious groups argue in favour of research cloning because of its potential to heal those who are sick. Many religious traditions such as Islam, Judaism, and some denominations in Christianity do not recognize the human embryo before 4 days after conception as an entity that should be accorded the same moral status as a person (NBAC 559). Among some of these traditions, there is also a strong commitment that faith must manifest in good works and that the world itself and the person within it should be objects of strenuous efforts to heal and improve human health. These religious traditions conceive and assert that the human embryo may have greater moral status than other collections of cells, but not so much that its cells may not be respectfully applied toward the other goals to which the faithful are committed.

In the light of the above, a pro-clonist, Nelson argued that most religious traditions that support cloning believe that the human embryos have moral status because they are alive and because they are alive they are valued to varying degrees by other moral agents (56). According to him, religious traditions that support human cloning do so, on the following grounds:

a. That only if the embryos and clones are used for human goals,

b. If only, the goal of the research cannot be obtained by other methods,

c. If only, those who use the embryos and clones avoid considering or treating them as property; and

d. If only, the destruction of the embryos and clones is accompanied by some loss or sorrow.

\section{APPRAISING HUMAN REPRODUCTIVE CLONING FROM AFRICAN TRADITIONAL CONTEXT}

Isiramen (90-96) in her article "Human Cloning: An African Response" anchored African traditional objections to human cloning on four basic African beliefs: origin of human life, goal of human life, gift of sexuality, and human spiritual status. The Africans believe traditionally that God is the creator of all things, including human life. The traditional belief that God is the creator of life is not different from the Biblical account of creation in Genesis 1:1-25. Hence, an African maxim says that: "All humans are the children of God; no one is a child of the earth" (Gyekeye, 1996, pp. 13). The Africans see God as the only Creator and Sustainer of life. From this stance, cloning is traditionally unacceptable since it is only God that can create human life. The uniqueness of life makes the Africans to consider human cloning as an attempt to reduce man to the level of sub-humans such as goats, monkeys, gorilla, etc. Human cloning traditionally in its strictness sense is considered to lead to the loss of human identity, quality and goal. This is because; the Africans believe that human existence is purposeful and resourceful. The phenomenon of cloning is also considered to lead to the manipulation and negation of the purposefulness and resourcefulness of human life on earth. As such, cloning is considered from the African traditional context as an aberration.

Next is the argument that human cloning negates human sexuality. The Africans believe that sexuality is a divine gift from God. Sexuality is highly respected by the Africans since it is 
believed to be the only means of procreation (Olasunkanmi, 2009, pp. 98). Hence to clone humans as a means of reproduction or procreation amounts to negation of the purpose of human sexuality and "an erosion of the ultimate outcome of sexual relationship between human persons." In this sense, a child raised outside sexuality, especially by cloning negates African culture. Such child may not be acceptable into an African traditional family. In this regard, a cloned child will become a loveless and miserable person in an African traditional society. The question about the humanity and spirituality of a clone pose another traditional objection to human cloning. The question is whether if a clone would possess a soul (i.e. spiritual identity). In African belief, every human being is made up of three principal substances - body, soul and spirit (Isiramen 196). The body is the tangible substance, while the soul and spirit are intangible substances.

The soul is the vital principle - the very essence of being, believed to be bestowed on humans at their pre-existence stage. Since the soul is immaterial, and cloning experts are only able to clone what is material, how would they be able to create a soul into such a clone? The simple answer will be that, clones will be soulless, thus, lacking spiritual identity. In the African traditional view, this raises objection to the authenticity of human clones. Other traditional objection to human cloning includes the argument that women will be unduly subjected to become reproduction machines and thus, radically exploited (Harris 353). This kind of subjection of the female folk is totally unacceptable to African culture. Africans' belief in the sacredness of life is another basis for the objection to human cloning. This is because, cloning experimentations involve multiple wastage of lives. In her concluding remarks, Isiramen (95) insisted that Africans should employ religious and legislative measures to ban the technology of cloning. By these measures and other anti-cloning activism, humanity will be safe and saved from impending future doom.

The smallest unit of human society is the family. The family has been called as the prime conversable ordinance, and in some traditions, a holily ordained institution for the bearing and nourishing of children. The concept of "Kinship" is chronic in the conception of "patronymic." Kinship is used to refer to people who descend from a usual ancestor or those who are affiliated by marriage. It is a group of human beings who are related by blood or who are socially related by marriage and owe themselves certain important social responsibilities. People who descend from a common ancestor are also refer to as "cognatic kin" or "cognate kin," for instance the Yoruba people believe that they all have a common ancestor who is called, Oduduwa, hence, we can refer to all the Yoruba people as cognate kin (Heabman 71 cited in Ottuh, 2008, pp. 226227; Drewal 2003, pp. 153). Another example is that of the Hausa people of Nigeria who trace their ancestral origin to "Bawo" who gave birth to Bayajidda, hence the whole of the Hausa people can be refer to as cognate kin (Ottuh, 2008, pp. 227). In its simplest form, kinship implies ties of blood or affiliation. In this way, a family kinship may be made up of grandfather, father, mother, brothers, sisters, uncle, or aunts and those who are related to each person by blood or marriage. In African, the family (kinship) pattern among a vast majority of African people is based upon polygamy. The diagrams in figures 2 and 3 clearly show the two ways (Family by Marriage and family by blood) that a family is constituted from an African traditional point of view. 
92 Jurnal Office: Jurnal Pemikiran Ilmiah dan Pendidikan Administrasi Perkantoran Vol. 6, No. 1, January-June 2020, Page 81-96

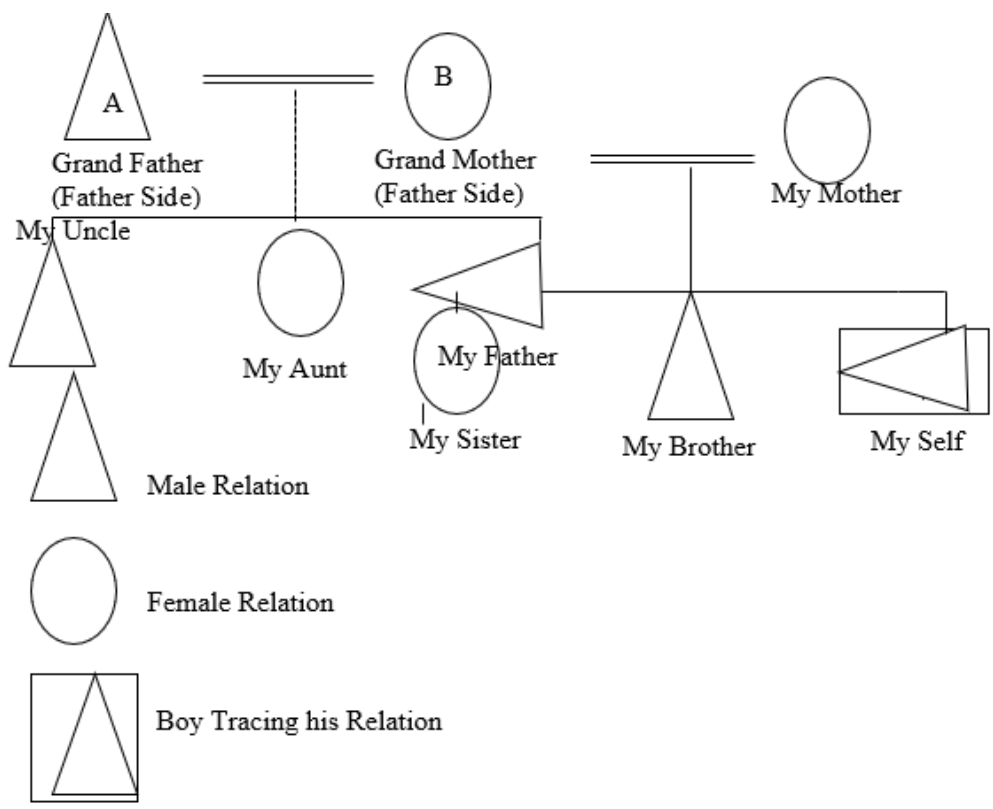

Source: (Heabman 13)

Figure 2

Family (or kinship) By Blood

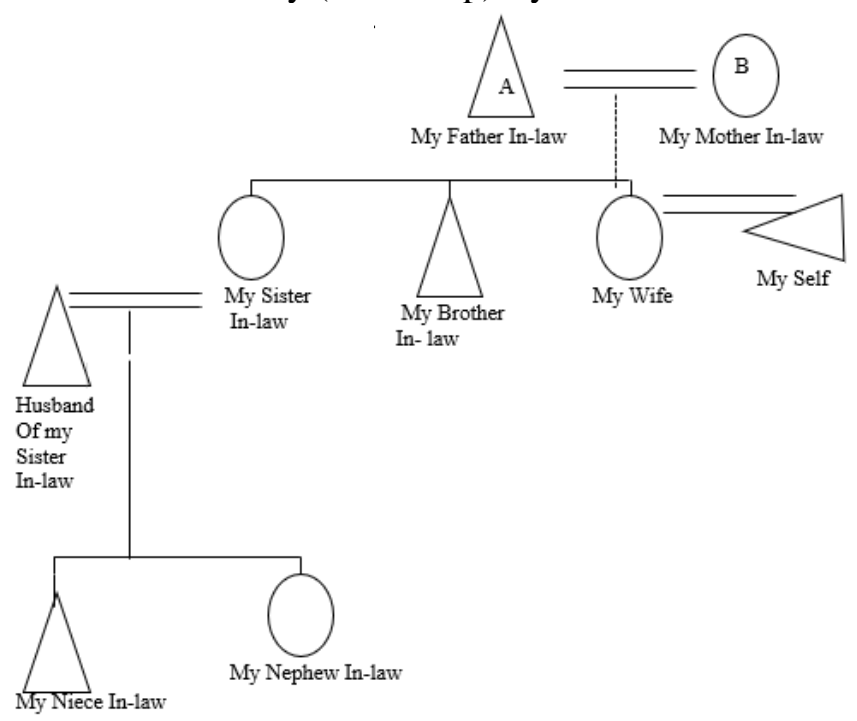

Source: (Heabman 14 cited in Ottuh, 2008, pp. 226-227)

Figure 3

Family (Kinship) By Marriage 
Taking a look at the above diagrams, one can discover that the "boy" traced his family relation to his "grand-father" and "grand-mother" through the father's side only. This means, that the "boy" in the diagram could inherit some property and position from his grand-father since they are related by blood. Secondly, he has the right to perform traditional ceremonies associated with his father's family without any discrimination. For instance, if his father is a title holder, i.e. an Oba, Chief, Emir, Ovie, etc, he has the right to compete for the throne with his kinsmen, i.e. his first cousin or even with his uncle. Also, he could partake in the extended family meetings. He also has the right to fair hearing among his kinsmen on the father's side. He could also share in the family lands. This means, when links are traced and rights and duties follow the male line, this type of family or kinship structure is referred to as patrilineal descent among the Yoruba of Nigeria (Peil 1977, pp. 1 cf. Drewal 2003, pp. 86). In the context of human cloning, the natural connection to one's family of origin also binds a person to the human world in ways that matter deeply.

Personal and social identity and social links of responsibility are united in countless ways to ties of biologic kindred. The psychical likeness of the cloned particular, already vex by a diminished sensibility of singularity as relate earlier, could be much further grieve by the peremptory bewilderment of kindred relations that would ensue from the circumstances of its origins. Just as the cloned special's recognition of individuality may be confused by his zero vectors, his connection to others, and expressly to their own genealogy, may become muddled as well (Kfoury 43). Moreover, this effect could be mirrored and amplified in the effect that cloning might have on the education of the patronymic, and the procession in which individuals and communities come to suppose of procreation. In this sense, the clone's position in the plant of human relations will be distrustful and disorganized. Also, the usual perspicuous designations of progenitor and generatrix, sister and brother, would be confounded. The clone would have only one genetic author, his or her intercourse to grandparents would span both one and two generations at once, and every other class description would be similarly disorganized.

It may be reasonably argued that some social arrangements already in existence break the link between natural kin and social family structure. A great many children, after all, are adopted, and live happy lives in loving families in the absence of biological connections with their parents. Some are also conceived via artificial insemination and various in vitro fertilization (IVF) techniques, and may have usual relationships with their genetic parents or no relationships at all. This is because all these existing arrangements attempt to emulate the model of the natural family, while cloning, on the other hand, actually runs against the grain of that model. In the case of adopted children, their connection to the parents who raise them is not biological, but it follows closely the model of the biological family unlike in the case of cloned children. In the opinion of the President's Council on Bioethics, it is argued that, "In most cases, on a loving union of the parents aimed at raising up new and unique individual whom the parents did not make but whom they wish to love, protect, and guide..." (PCB, 2009, pp. 1218). This implies that, it combines the same genetic uniqueness and the social connectivity of the biological parent-child relationship. Hence, nothing about the adopted child - parent relationship prevents the development of traditional familial bonds. The same is generally true of children conceived through in vitro fertilization (IVF) techniques. On the other hand, something about the relationship between the cloned child and the cloning parent may indeed interfere with the 


\section{4| Jurnal Office: Jurnal Pemikiran Ilmiah dan Pendidikan Administrasi Perkantoran \\ Vol. 6, No. 1, January-June 2020, Page 81-96}

development of these traditional social bonds (or relationships). This is because; the confusion created by the complicated relationship of cloning to clone may mean that new apparent lines of parent-child, sibling-sibling, or other hereditary kin relations will develop. These vital links could be exposed to serious shame and doubt, and so the fashion of the natural family would be very arduous if not impossible to emulate.

\section{CONCLUSION}

From the foregoing, human reproductive cloning tends to make bisexually a purely functional left over, given that an ovum must be used without its nucleus in order to make room for the clone-embryo requires a female womb so that its development may be brought to term. In reproductive cloning, women are radically exploited and reduced to a few of their purely biological functions (providing ova and womb) and research looks to the possibility of constructing artificial wombs, the last step to fabricating human beings. Human reproductive cloning must also be judged negative with regard to the dignity of the person cloned; who enters the world by virtue of being the "copy" of another being this practice paves the way to the clone's radical suffering for his psychic identity is jeopardized by the real or even by the merely virtual presence of his "other."

From an African traditional perspective, it implies that human fellowship or kinship can be a basis for the rejection of human reproductive cloning based on the worth of the human life as affirmed in some African maxim such as "It is the human being that counts; I call upon gold, it answers not; I call upon cloth, it answers not; It is the human being that counts" (Edor 2005). This means that the worth of human being ought to be given the ultimate consideration as this Akan maxim supports that: "The human being is more beautiful than gold". The bottom line is that human being should not be used as a means to an end. If man were to have the right to determine how human beings should come into being, he can also have the right to determine who should live and who not live. It would mean that man is absolute master of life. This is a negation of the prerogative of God (cf. Gen. 1:1 cf. Qur'an 11:23). In the final analysis, the thesis of this paper is very clear, that is, human reproductive cloning is totally condemnable and should not be practiced on human beings on the ground of unnaturalness, distortion, negation, imperfection, and aberration.

\section{REFERENCES}

Araujo, R. J. (2007). "The UN Declaration on Human Cloning: a survey and assessment of the debate". The National Catholic Bioethics Quarterly, 7, pp.129 - 149

Campbell, C. S. (2002). "Cloning Human Beings: Religions Perspectives on Human Cloning". A Paper Presented to U.S. National Bioethics Advisory Commission, Oregon State University.

Chung, Yang G. et al, (2014). Human somatic cell nuclear transfer using adult cells. Cell Stem Cell, 14(6), pp. 777-780 
De-Grey, A., \& Rae, M. (2007). Ending Aging: The Rejuvenation Breakthroughs that Could Reverse Human Aging in Our Lifetime. St. Martin's Press.

Drewal, H. J.(2003). "John Pemberton III and Rowland Abiodun, 'The Yoruba World"'. Death and the King's Horseman: Authoritative Text Backgrounds and Context Criticism. Edited by S. Gikandi, W.W. Norton \& Company, pp.69.

Edor, J. A., \& Odok, J. E. (2010). The Marxian School of Law and the Nigerian Legal System. The International Researcher, 4(1), 91-100.

Edor, J. E. (2005). The inductive predicament as an indispensable sable evil for practical life. Sophia: An African Journal of Philosophy, 8(1), 110-115.

Edor, J. E. (2016). Capital punishment: focus on the sanctity of human life in (Boki), Africa. Sapientia: Journal of Philosophy, 8(1), 86-102.

Edor, J. E. (2016). Wither the "Evil" of Capital Punishment: Focus on the Sixth Commandment of the Decalogue. The Oracle: International Journal of Culture, Religion and Society 3 (4), 102120

Gogarty, B. (2003). "What Exactly Is An Exact Copy? And Why It Matters When Trying To Ban Human Reproductive Cloning in Australia". Journals of Medical Ethics, 29, pp.8489

Haris, J. (1997). "Goodbye Dolly: The Ethics of Human Cloning”. Journal of Medical Ethics, no. 345, p. 353

Hefley, J. C. \& Lester, M. (1997). Human Cloning: Religions Response. Westminster John Knox, 1997.

Isiramen, C. O. (2001). "Human Cloning: An African Response". Iroro: Journal of Arts, 8(1 \& 2), pp.90-96

Isiramen, C. O. (2001). "Human Cloning: An African Response". Iroro: Journal of Arts, 8(1 \& 2) pp.90-96

Javitt, G. K. \& Hudson, K. (2006). Cloning: A Policy Analysis. Genetics and Public Policy Centre, 2006

Kennedy, D. (2007). "Responding to fraud". Science, vol. 31, no. 5804, 2006, pp.1353ff

Kfoury, C. "Therapeutic cloning: Promises and Issues". McGill Journal of Medicine, 10(2), pp.112-20.

Mullins, E. Y. (1972). The Christian Religion in Its Doctrinal Expression. Judson Press.

Nelson, R. G. (2009). "Cloning”. Retrieve from www.soc.enotes-com/ethics-humans-article, Nuclear Transfer. Retrieve from www.fosep.org/images/blas-tocyst2.gif , 2009 Human_Cloning_An_African_Perspective_by.pdf

Olasunkanmi, A. (2014). "Human Cloning: An African Perspective". International Journal of Humanities and Cultural Studies (IJHCS), vol. 1, no. 2, 2014.

Oregon Health \& Science University. (2013). "Human skin cells converted into embryonic stem cells: First time human stem cells have been produced via nuclear transfer". Science Daily, 155.

Ottuh, P. O. (2008). Human Cloning: A Philosophico-Thgeological Appraisa. (unpublished Ph.D Thesis). Ambrose Alli University, 2008

Peil, Margaret. Consensus and Conflicts in Africa Societies: An Introduction to Sociology of Religion. Longmans, 1977. 


\section{6| Jurnal Office: Jurnal Pemikiran Ilmiah dan Pendidikan Administrasi Perkantoran}

Vol. 6, No. 1, January-June 2020, Page 81-96

Peters, T. (2001). Embryonic Stem Cells and the Theology of Dignity. The Human Embryonic Stem Cell Debate, Science, Ethics, and Public Policy. Edited by S. Holland, K. Lebacqz \& L. Zoloth. Massachusetts Institute of Technology Press, pp.128-130.

Seyyed, H. A. (2007). Human Cloning in Catholic and Islamic Perspectives. University of Religions and Denominations.

Stone, R.H. \& Cozens, A.B. (1975). New Biology for West African Schools. Longmans, 1975

The President's Council on Bioethics (2009). Working Paper 3b. Retrieve from www.bioethics.gov/background/workingpaper 3 b.html,

Thomas, I. (2013). Should scientists pursue cloning? Raintree.

Varga, A. (1980). The Issues in Bioethics. Paulist Press.

Zhu, Z., \& Huangfu, D., (2013). Human pluripotent stem cells: an emerging model in developmental biology. Development, 140(4), pp.705-71. 